\title{
NCTM's Principles and Standards for Developing Conceptual Understanding in Mathematics
}

\author{
Saleh Haji ${ }^{*}$ and Yumiati ${ }^{2}$

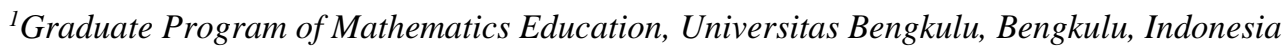 \\ ${ }^{2}$ Graduate Program of Mathematics Education, Universitas Terbuka, Indonesia
}

\begin{abstract}
The purpose of this study is to develop understanding of concepts in mathematics through the application of the NCTM's Principles and Standards. This research method is descriptive. The results obtained are understanding concepts in mathematics can be developed through the application of NCTM Principles and Standards consisting of 6 principles, namely: 1. Equity, 2. Curriculum, 3. Teaching, 4. Learning, 5. Assessment, and Technology. Understanding concepts in mathematics that can be developed are: a. defining concepts verbally and in writing, b. Make examples and not examples, c. Using various symbols to present a concept, $d$. Change the form of representation to various forms, e. Identifying the characteristics of a concept, f. compare various concepts, and g. interpret concepts.
\end{abstract}

Keyword: NCTM's Principles and Standards, Conceptual Understanding

\begin{abstract}
Abstrak. Tujuan dari pembelajaran ini adalah untuk mengembangkan pemahaman pada konsep matematika melalui aplikasi dari prinsip dan standard NCTM. Metode penelitian ini bersifat deskriptif. Hasil yang diperoleh adalah pemahaman konsep pada matematika dapat dikembangkan melalui aplikasi dari prinsip dan standard NCTM yang terdiri atas 6 prinsip, yaitu: 1. Kesetaraan, 2. Kurikulum, 3. Mengajar, 4. Pembelajaran, 5. Penilaian dan Teknologi. Pemahaman konsep pada matematika yang dapat dikembangkan adalah: a. mendefinisikan konsep secara lisan dan tertulis, b. buat contoh dan bukan contoh, $c$. menggunakan sejumlah simbol untuk menyatakan suatu konsep, $d$. mengubah bentuk representasi ke berbagai bentuk, e. mengidentifikasi karakteristik dari suatu konsep, $f$. membandingkan sejumlah konsep dan g. menginterpretasikan konsep.
\end{abstract}

Kata Kunci: Prinsip dan Standard NCTM, Pemahaman Konseptual

Received 15 April 2019| Revised 05 July 2019| Accepted 23 September 2019

\section{Introduction}

Many students experience difficulties in learning mathematics, especially elementary school students. Mathematics is still a problem for students in elementary schools in particular. The research findings in basic education are generally about fractions / arithmetic, geometry, and story problems [1]. While in secondary education about building space and higher education about limits. Other findings related to students' difficulties and weaknesses in understanding

\footnotetext{
*Corresponding author at: Universitas Bengkulu, Bengkulu, Indonesia
} 
mathematical concepts [2]. The under the 35th percentile, elementary school students experience difficulties in learning mathematics [3].

Many factors make students experience difficulties (weaknesses) in understanding mathematical concepts. Some of the main factors that lead to students' learning in mathematics [4]. They are learning disabilities in mathematics [5], unsatisfactory teaching [6], lack of infrastructure and school funding [7], and the lack of a learning assessment system (procedure) [8]. To overcome the difficulties (weaknesses) of students in understanding the concepts in mathematics, it is necessary to comprehensively improve the various factors that influence it. These factors are found in the principles and standards for school mathematics namely equity, curriculum, teaching, learning, assessment, and technology [9].

For example, in these principles and standards in the learning aspect explained that in learning mathematics especially in understanding mathematical concepts, students build their own mathematical knowledge. The American National Research Council suggests that students can learn mathematics well only when they build their own mathematical understanding by examining, representing, changing, solving, applying, proving, and communicating mathematical ideas [10].

Some research results show that the application of principles and standards for school mathematics in mathematics learning can overcome the problems of student weaknesses in mathematics. One of the main tenets in the NCTM standards is commitment to providing highquality mathematical experiences to all students [11]. The principles and standards for NCTM (School Mathematics comprehensive reference on developing mathematical knowledge [12]. The NCTM's Principles and Standards Principles can streamline the processes and products of mathematics learning in developing differences in students' abilities in their processes and products [13].

Understanding the mathematical concepts developed through NTCM's Principles and Standards is an understanding of: 1) defining concepts verbally and in writing; 2) making examples and not examples; 3 ) using various symbols to present a concept; 4) changing the form of representation into various forms; 5) identifying the characteristics of a concept; 6) comparing various concepts; and 7) interpret the concept.

The ability to understand concepts is a very important ability in learning mathematics. The conceptual understanding is an important component of proficiency [9]. The mathematics learning needs to be directed to develop understanding of concepts [14]. Students who understand concepts in mathematics, then he can use the concept to solve various problems in mathematics and problems outside mathematics.

The problem formulation in this research is how does NTCM's Principles and Standards build students' understanding of concepts in mathematics?

\section{Methodology}

This research method is a qualitative descriptive research method, a type of document analysis. The type of document analysis research (content analysis) is a description of an object systematically [15]. The object in the form of NCT's Principles and Standards was studied systematically and qualitatively so that it was obtained in relation to the understanding of concepts 
in mathematics. The relationship between these two aspects can form a theory. The qualitative method is best used to develop a theory [16]. The object of this research study consists of two aspects namely NCT's Principles and Standards and Conceptual Understanding in Mathematics.

The main instrument of this research is the researchers themselves who found data about NCT's Principles and Standards and Conceptual Understanding in Mathematics. A role in determining the overall scenario of the study [17]. Data analysis used is qualitative analysis. The qualitative data analysis is an ongoing, repetitive and continuous effort. The stages of qualitative data analysis consist of: a. Data collection, b. Data reduction, c. Presentation of data, and d. Conclusions.

\section{Results and Discussion}

The concept in mathematics is interpreted as an abstract idea that can be used to classify a set of objects [1]. The ability to classify a set of objects in mathematics is interpreted as a conceptual understanding ability. Like the ability of students to classify a set of numbers which are real numbers. Real numbers $(\mathrm{R})$ contain natural numbers $(\mathrm{N})$, integers $(\mathrm{Z})$, and rational numbers $(\mathrm{Q})$. Symbolically written as $\mathrm{N} \subset \mathrm{Z} \subset \mathrm{Q} \subset \mathrm{R}$.

The indicators of understanding concepts consist of: 1 . defining concepts verbally and writing, 2 . making examples and not examples, 3. using various symbols to present a concept, 4. changing the form of representation to various forms, 5. Identify the nature of a concept, 6 . compare various concepts, and 7. interpret concepts [10]. The seven indicators of understanding the concept are the focus of this study. In addition, indicators of understanding a concept in mathematics are also expressed by other experts.

In order to understand a concept in mathematics, students must know: a. object discussed, and b. the relation of the object to other similar and non-similar objects [18]. The understanding of mathematical concepts consisting of instrumental understanding with relational understanding [19]. The instrumental understanding as an understanding of mutually separate concepts and relational understanding as structured understanding used to solve broader problems [20]. The characteristics of students who have understood a concept in mathematics, namely students can: a. explain the meaning of a concept, b. make a logical connection between concepts, and c. combining relationships between concepts in new situations [21].

The ability to understand concepts in mathematics can be developed through the application of NCTM's Principles and Standards, namely: 1. Equity, 2. Curriculum, 3. Teaching, 4. Learning, 5. Assessment, and 6. Technology.

1. Equity

Excellence in mathematics education requires equity, high expectations and strong support for all students [9]. The mathematical learning for all students. Learning mathematics is the right of every student without regard to the conditions and background of students. Every student has the same opportunity to learn mathematics [22]. The similarity factor in mathematics learning especially in terms of assessing student learning outcomes is very important for teachers to build effective mathematics learning [23]. Similarity factors in learning mathematics provide 
motivation for students to learn concepts in mathematics with a feeling of security and a free atmosphere.

It is this safe and free atmosphere that can help students understand a concept in mathematics. Students can: 1 . define concepts verbally and writing, 2. make examples and not examples, 3. use various symbols to present a concept, 4 . change the form of representation to various forms, 5 . identify the properties of a concept, 6 . comparing various concepts, and 7. interpreting concepts. Like can give examples of the concept of triangles and non-triangles.

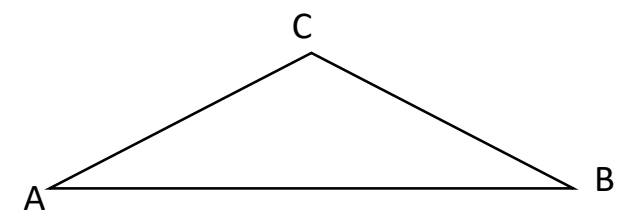

Figure 1 Example of the concept of triangles and non-triangles.

\section{Curriculum}

The curriculum is more than a collection of activities: it must be coherent, focused on important mathematics, and well articulated across the grades [9]. The coherence of the mathematics curriculum contains the linkages of various units / topics / concepts and accommodates various mathematical ideas that are important for the development of mathematics itself or other sciences as well as for solving coherent problems in daily life. For example, the relationship between exponential concepts and multiplication is $a^{n}=a \times a \times a \times \ldots \times a$ where $a$ is $n$ factors. Topics of multiplication are taught in elementary school followed by the same topic as the expansion and deepening of material in junior high schools, then associated with exponential topics in Senior High School. Likewise the relationship between the concepts of sets, relations, ordered pairs, and functions. The concepts are given starting from elementary school, junior high school, to senior high school in the KTSP and K-13 curriculum.

The connection of various topics can make the concept more meaningful and easier for students to understand. Because the earlier concept can make it easier to understand the next concept. The curriculum taught through meaningful mathematics and comprehensive curricula [22]. Linkages between topics and concepts in mathematics as logical implications of mathematics as a science of organized structures [24].

The mathematics curriculum should contain things that are important and meaningful for the lives of students for their life needs and to be able to continue their next education. Such a topic about counting operations is one of the most important topics in mathematics. It is important to be able to solve a problem. Therefore, the selection of material in the curriculum is done selectively. The curriculum should only contain material selected selectively according to the needs and progress to be achieved [1].

The mathematics curriculum that is presented coherently and contains important material for students can develop the ability to understand concepts in seven aspects of conceptual understanding indicators by NCTM. A coherent curriculum allows students to: 1 . define concepts verbally and in writing, 2. make examples and not examples, 3. use various symbols to present a concept, 4. change the form of representation to various forms, 5. identify the properties of a concept, 6. comparing various concepts, and 7. interpreting concepts. 


\section{Teaching}

The effective teaching requires understanding what students know and need to learn and then challenging and supporting them to learn it well [9]. Teaching mathematics must be able to know what students know and what students need and provide challenges to students. In addition, teaching mathematics must be oriented to students' knowledge and understanding of a mathematical concept. The knowledge and understanding of mathematics is built by students themselves through various activities. The effective teaching requires knowing and understanding mathematics, students as leaners and pedagogical [9]. To develop student activities in understanding mathematics, mathematics must be seen as a human activity. The mathematics as a human activity [25].

Effective teaching of mathematics requires knowledge and understanding of mathematics, students as lean and pedagogical strategies. Teaching such mathematics can improve students' mathematical abilities (concept understanding). This is shown in Figure 2 below.

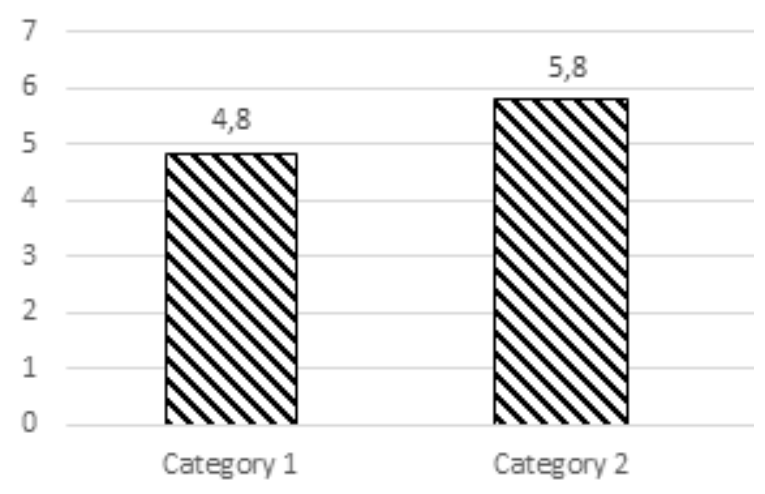

Figure 2 Mathematical abilities (Formulating Algebraic) students taught through NCTM's Standard and Principles (Category 2) and Traditional Teaching (Category 1) [26].

To develop understanding students need to be supported by competent teachers. Referring to the competent and caring teachers who work towards having students understand and be able to use mathematics [22].

Understanding mathematics teaching will give students the opportunity to argue (opinion). The findings that understanding-based teaching approaches (arguments) can enhance students' conceptual understanding [27]. The argument is conveyed systematically by using concept maps to solve a problem. The problem solving is one of the principles in teaching mathematics [28]. The the use of Concept Maps in teaching mathematics can improve understanding of concepts and be able to build more representations of these concepts [29].

Understanding mathematics teaching will give students the opportunity to argue (opinion). The findings that understanding-based teaching approaches (arguments) can enhance students' conceptual understanding [27].

The argument is conveyed systematically by using concept maps to solve a problem. The problem solving is one of the principles in teaching mathematics [28]. The use of Concept Maps in teaching mathematics can improve understanding of concepts and be able to build more representations of these concepts [29]. 
The principles of teaching based on the NCTM can develop the ability to understand mathematical concepts in terms of defining a concept, combating between examples and not examples of concepts, applying concepts to new situations, and others.

\section{Learning}

The students must learn mathematics with understanding, actively building new knowledge from experience and prior knowledge [9]. Focus on learning mathematics on aspects of understanding, prior knowledge that students understand and active student involvement in building new knowledge. The mathematics teaching and learning process needs to emphasize more on student involvement in an optimal manner consciously [1]. The involvement of students in learning mathematics can make it easier for them to gain meaningful understanding of concepts.

Such understanding of the concept of "fractions" is understood by students through a series of activities carried out as follows: drawing a circle on a piece of paper, then cutting it into several equal parts, then comparing the pieces of paper to obtain an understanding of the concept of fractions. The NCTMs Principles and Standars oriented The Core Plus Mathematics Project Curriculum (CPMP) making students more involved in the problem solving process [30]. They look for an alternative solution process; they work together as a group; and they show more steps in written work.

The involvement of students starts from the beginning of learning until the end of learning. The involvement of students is in the form of delivering arguments that support the understanding of concepts. Such as student involvement in understanding the concept of fractions. At first the students cut a square paper into several equal parts. Then students compare the pieces of paper with the number of pieces of paper thoroughly. Then the students conclude about fractions. The concept of fractions that students have understood is used to understand other concepts of mathematics, such as the concept of comparison. The establishing programs that enable students to solve problems will inevitably face in the future. All students to understand and use mathematics [22].

Through the principle of learning based on the NCTM, it can develop an understanding of students' mathematical concepts in terms of defining concepts, classifying concepts, applying concepts in others.

\section{Assessment}

The assessment should support the learning of important mathematics and furnishings [9]. Useful information to both teachers and students. Assessment of mathematics learning is intended for all students and teachers to improve learning. Employing the kind of assessment that informs teaching as well as monitors, enhances and evaluates the learning of all students [22].

For students the assessment is useful for improving mathematical abilities (understanding of concepts) which includes the goal of conceptual understanding indicators by NCTM. As for teachers, assessment is useful for increasing the effectiveness of learning related to the model / method / technique / teaching strategy, media, learning resources, learning environment, and evaluation tools. 
Feedback for students through assessment provides awareness to improve their understanding of mathematical concepts. The continuous feedback and improvement process will be able to develop the mathematical concept capabilities.

\section{Technology}

The technology is essential in teaching and learning mathematics; it influences the mathematics that is taught and enhances students' learning [9]. The role of technology is to facilitate students in understanding mathematical concepts. The concepts in mathematics can easily and attractively be presented visually by technology. Like the concept of building a pyramid, cube, ball, and prism. So that through the use of technology, students can fulfill the seven concept understanding indicators from NCTM. Students can make the definition of the cube correctly, and can distinguish between cubes and non-cubes.

In addition, technology can streamline mathematics learning. Through the use of a calculator you can quickly obtain the results of the count operation in numbers. By using technology in teaching mathematics, students do not miss the times. Used to enhance understanding in a program that prepares students to use mathematics and the technological world [22].

\section{Conclusion and Suggestion}

The results obtained are understanding concepts in mathematics can be developed through the application of the NCTM Principles and Standards consisting of 6 principles, namely: 1. defining concepts verbally and in writing, 2 . making examples and not examples, 3 . using various symbols to present a concept, 4 . Change the form of representation to various forms, 5. Identify the nature of a concept, 6. compare various concepts, and 7. interpret concepts.

To develop students' understanding of mathematical concepts, it is best to apply NCTM standards and principles about mathematics teaching in schools and in the mathematics curriculum.

\section{REFERENCES}

[1] R. Soedjadi, "Kiat Pendidikan Matematika di Indonesia", Departemen Pendidikan Nasional, Jakarta, 1999/2000.

[2] L. B. Hanich, N. C. Jordan, D. Kaplan and J. Dick, "Performance across Different Areas of Mathematical Cognition in Children with Learning Difficulties", Journal of Educational Psychology, vol. 93, no. 615, http://dx.doi.org/10.1037/0022-0663.93.3.615, 2001.

[3] N. C. Jordan, L. B. Hanich and D. Kaplan, "A Longitudinal Study of Mathematical Competencies in Children with Specific Mathematics Difficulties versus Children with Comorbid Mathematics and Reading Difficulties", Child Development, vol. 74, pp. 834850. http://dx.doi.org/10.1111/1467-8624.00571, 2003.

[4] B. R. Acharya, "Factors Affecting Difficulties in Learning Mathematics by Mathematics Learners", International Journal of Elementary Education, vol. 6, no. 2, pp. 8-15, 2017.

[5] R. Hall, "An Introduction to Children with Special needs for Teachers in Mainstream Schools", Wirui Press, Wewak, PNG, 1994.

[6] L. Mundia, "The Assessment of Math Learning Difficulties in a Primary Grade-4 Child with High Support Needs: Mixed Methods Approach", International Electronic Journal of Elementary Education, vol. 4, no. 2, pp. 347-366, 2015. 
[7] M. J. Kelly, "Education in a Declining Economy. EDI Development Policy Case Series", World Bank, Washington, D.C., 1991.

[8] D. Murray, "Forget Charity? We have a Right to Fair Assessment: Accommodating Student with Disabilities Need Not Compromise Assessment Standards", An unpublished paper presented at a conference on "Partnerships on the Assessment of Student Achievement" held in Auckland, New Zealand, September 22-28, 1996.

[9] NCTM, "Principles and Standards for School Mathematics", The National Council of Teachers of Mathematics, Inc, USA, 2000.

[10] NCTM, "Assessment Standard for School Mathematics", The National Council of Teachers of Mathematics, Inc, USA, 1989.

[11] NCTM, "The Nature and Role of Algebra in The K-14 Curriculum. Proceedings of a National Symposium", National Academy Press, Washington, D.C., 1997.

[12] NCTM, "Curriculum Focal Points for Prekindergarten through Grade 8 Mathematics", 2006.

[13] J. F. Mundy, "Principles and Standards for School Mathematics: A Guide for Mathematicians", Notices of The AMS, vol. 47, no. 8, 2000.

[14] U. Sumarmo, "Alternatif Pembelajaran Matematika dalam Menerapkan Kurikulum Berbasis Kompetensi”. Seminar Nasional FMIPA UPI: Tidak diterbitkan, 2002.

[15] I. Latunussa, "Penelitian Pendidikan Suatu Pengantar", Departemen Pendidikan dan Kebudayaan, Jakarta, 1988.

[16] Sugiyono, "Metode Penelitian Kuantitatif, Kualitatif, dan R \& D", Alfabeta, Bandung, 2010.

[17] L. J. Moleong, "Metodologi Penelitian Kualitatif”, PT Remaja Rosdakarya, Bandung, 2010.

[18] E. R. Michener, "Understanding Mathematics", Cognitive Science, vol. 2, pp. 361-383, 1978.

[19] A. Poolatsek, S. Lima and A.B. Well, "Concept or Computation: Students Understanding of The Mean”, Educational Studies in Mathematics, vol. 12, pp. 191-204, 1981.

[20] U. Sumarmo, "Kemampuan Pemahaman dan Penalaran Matematika Siswa SMA Dikaitkan dengan Kemampuan Penalaran Logik Siswa dan Beberapa Unsur Proses Belajar Mengajar, Disertasi”, Fakultas Pasca Sarjana, IKIP Bandung, 1987.

[21] P. Alfeld, "Understanding Mathematics". [Online]. Tersedia: http://www.math.utah.edu/pa/math.html. [30 Desember 2008], 2004.

[22] D. L. Ronis, "Performance-Based Learning and the NCTM Recommendations", Paper presented at the Annual Meeting of the Association for Supervision and Curriculum Development (San Francisco, CA, March 6-8, 1999), 1999.

[23] C. Morgan and A. Watson, "The Interpretative Nature of Teachers' Assessment of Students' Mathematics: Issues for Equity", Journal for Research in Mathematics Education, vol. 33, no. 2, pp. 78-110, 2002.

[24] H. E. T. Ruseffendi, "Pengantar Kepada Membantu Guru Mengembangkan Kompetensinya dalam Pengajaran Matematika untuk Meningkatkan CBSA", Tarsito, Bandung, 1991.

[25] Suryanto, "Sejarah Pendidikan Matematika Realistik Indonesia", Direktorat Jenderal Pendidikan Tinggi, Jakarta, 2010.

[26] S. Kramer, "The Joint Impact of Block Scheduling and an NCTM Standards-based Curriculum on High School Mathematics Achievement", 2003.

[27] D. Cinar and S. Bayraktar, "Evaluation of The Effecs of Argumentation Based Science Teaching on $5^{\text {th }}$ Grade Students' Conceptual Understanding of The Subject Related to "Matter and Change" ", International Journal of Education in Mathematics, Science, and Technology (IJEMST), vol, 2, no. 1, pp. 49-77, 2014. 
[28] L. J. Brueckner, F. E. Grossnickle and J. Reckzeh, "Developing Mathematical Understandings", Holt, Reinehart, and Winston, Inc, New York, 1991.

[29] D. Serhan, M. Syam and Q. Almdallal, "The Effect Maps on Advancing Student's Conceptual Understanding of Euler Circuit", International Journal of Mathematics Trends and Technology, vol. 15, no. 1, 2014.

[30] C. M. Latterral, "Testing the Problem-Solving Skills of Students in an NCTM-oriented Curriculum", The Mathematics Educator, vol. 13, no. 1, pp. 5-14 2003.

[31] Y. S. Matros and G. A. Bunimovich, "Reverse-flow operation in fixed bed catalytic reactors", Catalysis Reviews: Science and Engineering, vol. 38, pp. 1-66, 1996.

[32] A. Nuryaman, A. Y. Gunawan, K. A. Sidarto and Y. W. Budhi, "A Singular Perturbation Problem for Steady State Conversion of Methane Oxidation Process in Reverse Flow Reactor", ITB Journal of Science, vol. 44A, no. 3, pp. 277-287, 2012.

[33] A. Nuryaman and A. Y. Gunawan, "A Singular Perturbation Problem in Steady State of Methane Combustion Using Reverse Flow Reactor", Far East Journal of Mathematical Sciences (FJMS), vol. 102, no. 9, pp. 2069-2079, 2017.

[34] J. Khinast, Y. O. Jeong and D. Luss, "Dependence of Cooled Reverse-Flow Reactor Dynamics on Reactor Model", AIChE Journal, vol. 45, no. 2, pp. 299-309, 1999.

[35] P. V. Dankwerts, "Continous Flow System: Distribution of Residence Times", Chem. Eng. Sci., 2: pp. 1-13, 1953.

[36] T. L. V. Noorden, S. M. V. L. Verduyn and A. Bliek, "The Efficient Computation of Periodic States of Cyclically Operated Chemical Processes", IMA Journal of Applied Mathematics, 68, pp. 149-166, 2003.

[37] J. H. He, "Homotopy Perturbation Technique", Comput. Math. Appl. Mech. Eng, vol.178, no. 3-4, pp. 257-262, 1999.

[38] L. Jin, "Homotopy Perturbation Method For Solving Partial Differential Equations With Variable Coefficient", Int. J. Contemp. Math. Sciences, vol. 3, no. 28, pp. 1395-1407, 2008.

[39] J. W. Thomas, Numerical Partial Differential Equations: Finite Difference Method, Springer, New York, USA, 1995. 